\title{
Optimization of Cost and CO2 Emission in Reinforced Concrete Footings Using a Metaheuristic Algorithm: A parametric study
}

\author{
Carlos Millán-Páramo ${ }^{1}$, Euriel Millán-Romero ${ }^{2}$ and Fernando Jove Wilches ${ }^{1}$ \\ ${ }^{1}$ Department of Civil Engineering, Universidad de Sucre, Sincelejo, Sucre, Colombia. \\ ${ }^{2}$ Faculty of Engineering, Universidad de Sucre, Sincelejo, Colombia. \\ *Corresponding author:fernando.jove@unisucre.edu.co
}

ORCIDs: 0000-0002-0004-6063 (Carlos), 0000-0001-7955-9963 (Euriel), 0000-0002-2080-4036 (Fernando)

\begin{abstract}
It is necessary to build structural elements that are economical and that in turn support the loads to which they are subjected. On the other hand, it is important to control $\mathrm{CO} 2$ emissions in construction processes. The excess of this gas is the main cause of global warming by the greenhouse effect. In this context, this work presents a sensitivity analysis to assess the impact of different design parameters on the optimization of cost and $\mathrm{CO} 2$ emission of reinforced concrete footings. The design parameters are applied load, soil elastic modulus, Poisson ratio, angle of internal friction, factor of safety and allowable settlement. For this, the metaheuristic called Modified Simulated Annealing Algorithm is used to obtain the optimal designs.
\end{abstract}

Keywords: Reinforced concrete footings, cost and $\mathrm{CO} 2$, optimal design, metaheuristics.

\section{INTRODUCTION}

The footings are structural members that serves as a foundation for a pillar, wall or other surface element, transmitting the efforts it receives from it to the ground. These can fail due to the shear break of the soil that supports it. However, prior to the occurrence of shear failure in the soil, and even if it does not, it is also possible that a superficial foundation is subjected to a settlement sufficiently large to cause damage to the structure and make it dysfunctional for the purpose for which was designed [1].

Designing economic structural elements is essential in engineering practice [2]. There are recently developed methods for the low-cost design of reinforced concrete footings $[3,4]$ and this problem has been the subject of studies in the literature in the recent years. On the other hand, greenhouse gases have increased significantly due to human activity. Due to this, more sustainable design methods and construction practices are being used, which positively impacts the reduction of $\mathrm{CO} 2$ emissions. However, reducing cost and $\mathrm{CO} 2$ emissions is a difficult task to solve. This type of problems presents multidimensional search spaces and a high number of restrictions, requiring a powerful optimization tool.

Modified simulated annealing algorithm (MSAA) is a simple single-solution algorithm based on the behavior of atomic arrangements in liquid or solid materials during the annealing process introduced by Millan et al. [5] and it has been shown to be a computationally efficient metaheuristic method to solve a variety of optimization problems [6-13]. MSAA is a newly improved version of the simulated annealing (SA) algorithm with three modifications. Firstly, a preliminary exploration is realized to choose the starting point of search. Secondly, the transition from the starting point to the new point is done by a search step. Thirdly, the range of probability of accepting a worse solution is reduced.

The aim of this work is performance a sensitivity analysis to assess the impact of different design parameters on the optimization of cost and $\mathrm{CO} 2$ emission of reinforced concrete footings using Modified simulated annealing algorithm. The remainder of this paper is organized as follows. In Section 2, the methodology is described. Section 3 presents the results and discussions. Finally, in Section 4, our conclusions are presented.

\section{METHODOLOGY}

The procedure is divided into three stages: (i) formulation of geotechnical limit states (ii) formulation of the optimization design of reinforced spread footings and (ii) metaheuristic algorithm to solve the optimization problem.

\section{II.I. Geotechnical limit states}

Two criteria must be considered, regarding the geotechnical aspect in the design of isolated footings: achieving the base safety factor and not exceeding the permissible settlement value. Figure 1 shows the general dimensions of an isolated footing, assumed as squared. Geotechnical formulation is shown in Table 1. 


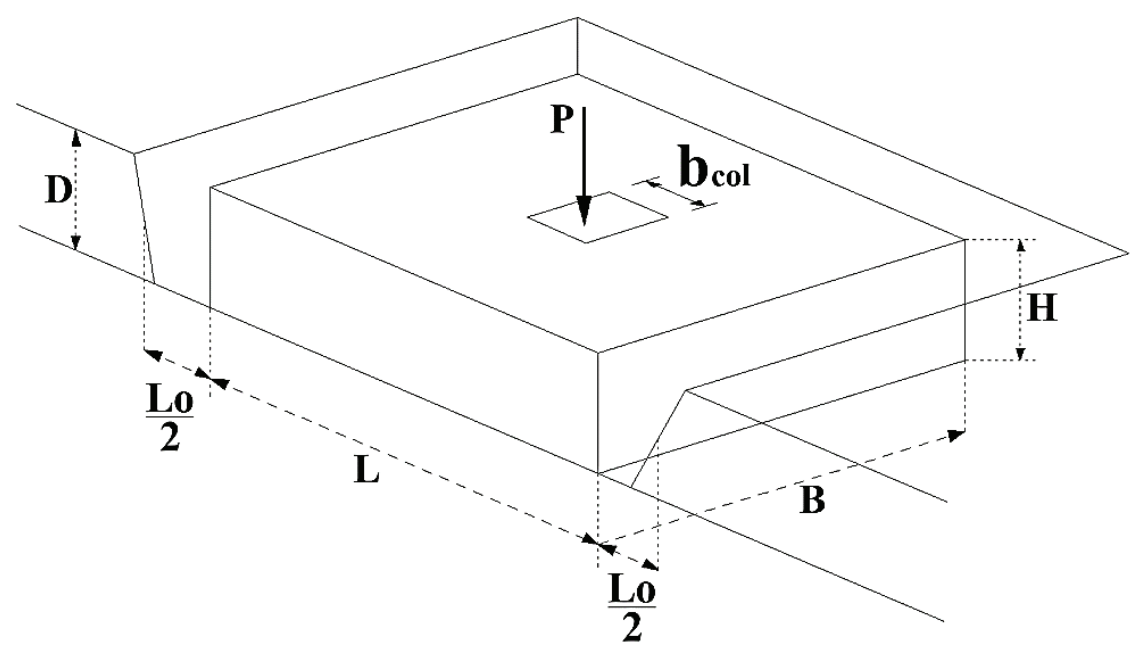

\section{L: length}

B: width

H: thickness

D: height from footing base to ground level

$\mathrm{L}_{\mathrm{o}}+\mathrm{L}$ : excavation width

$\mathrm{B}_{\mathrm{o}}$ : excavation length

$\mathrm{b}_{\text {col: }}$ : column width

P: applied vertical service load

Fig. 1. Spread footing dimensions

Table 1. Geotechnical formulation

\begin{tabular}{|c|c|c|}
\hline $\mathrm{q}=\frac{\mathrm{P}+\mathrm{W}_{\mathrm{f}}}{\mathrm{BL}}$ & (1) & $\begin{array}{l}\mathrm{q} \rightarrow \text { uniformly distributed stress over the soil } \\
\mathrm{W}_{\mathrm{f}} \rightarrow \text { weight of any overload on the footing (including the weight of } \\
\text { the footing itself) }\end{array}$ \\
\hline $\mathrm{FS}_{\mathrm{B}}=\frac{\mathrm{q}_{\mathrm{ult}}}{\mathrm{q}}$ & (2) & $\begin{array}{l}\mathrm{FS}_{\mathrm{B}} \rightarrow \text { base safety factor } \\
\text { qult } \rightarrow \text { is the ultimate bearing capacity of the footing }\end{array}$ \\
\hline $\mathrm{q}_{\mathrm{ult}}=\mathrm{cN}_{\mathrm{c}} \mathrm{F}_{\mathrm{cs}} \mathrm{F}_{\mathrm{cd}}+\gamma \mathrm{DN}_{\mathrm{q}} \mathrm{F}_{\mathrm{qs}} \mathrm{F}_{\mathrm{qd}}+0.5 \gamma \mathrm{BN}_{\gamma} \mathrm{F}_{\gamma \mathrm{s}} \mathrm{F}_{\gamma \mathrm{d}}$ & (3) & $\begin{array}{l}\gamma \rightarrow \text { foundation soil specific weight } \\
\mathrm{c} \rightarrow \text { foundation soil cohesion } \\
\mathrm{N}_{\mathrm{c}}, \mathrm{N}_{\mathrm{q}} \text {, and } \mathrm{N}_{\gamma} \rightarrow \text { dimensionless bearing capacity factors (being only } \\
\text { functions of the foundation soil friction angle - ) } \\
\mathrm{F}_{\mathrm{cs}}, \mathrm{F}_{\mathrm{qs}} \text {, and } \mathrm{F}_{\gamma_{\mathrm{s}}} \rightarrow \text { shape factors } \\
\mathrm{F}_{\mathrm{cd}}, \mathrm{F}_{\mathrm{qd}} \text {, and } \mathrm{F}_{\gamma d} \rightarrow \text { depth factors }\end{array}$ \\
\hline $\mathrm{N}_{\mathrm{q}}=\mathrm{e}^{\pi \tan \phi} \tan ^{2}\left(\frac{\pi}{4}+\frac{\phi}{2}\right)$ & (4) & \multirow{9}{*}{$\phi \rightarrow$ internal friction angle of the soil } \\
\hline $\mathrm{N}_{\gamma}=2\left(\mathrm{~N}_{\mathrm{q}}+1\right) \tan \phi$ & (5) & \\
\hline $\mathrm{F}_{\mathrm{qs}}=1+\frac{\mathrm{B}}{\mathrm{L}} \tan \phi$ & (6) & \\
\hline $\mathrm{F}_{\gamma \mathrm{S}}=1-0.4 \frac{\mathrm{B}}{\mathrm{L}}$ & (7) & \\
\hline $\mathrm{F}_{\mathrm{qd}}=1+2 \tan \phi(1-\sin \phi)^{2} \mathrm{U}$ & (8) & \\
\hline $\mathrm{U}=\left[\arctan \left(\frac{\mathrm{D}}{\mathrm{B}}\right)\right]$ & (9) & \\
\hline $\mathrm{F}_{\mathrm{qd}}=1+2 \tan \phi(1-\sin \phi)^{2}\left(\frac{\mathrm{D}}{\mathrm{B}}\right)$ & (10) & \\
\hline $\mathrm{F}_{\gamma \mathrm{d}}=1$ & (11) & \\
\hline $\mathrm{F}_{\mathrm{cs}}=1-\frac{\mathrm{BN}_{\mathrm{q}}}{\mathrm{LN}_{\mathrm{c}}}$ & (12) & \\
\hline \multicolumn{3}{|l|}{$\mathrm{F}_{\mathrm{cd}}$ values according to Arrieta [13] } \\
\hline$\delta=\frac{\left(\mathrm{P}+\mathrm{W}_{\mathrm{f}}\right)\left(1-v^{2}\right)}{\beta_{\mathrm{z}} \mathrm{E} \sqrt{\mathrm{BL}}}$ & (13) & $\begin{array}{l}\delta \rightarrow \text { settlements of the foundation } \\
\nu \rightarrow \text { Poisson's coefficient } \\
E \rightarrow \text { module of elasticity of the soil }\end{array}$ \\
\hline$\beta_{z}=-0.0017\left(\frac{L}{B}\right)^{2}+0.0597\left(\frac{L}{B}\right)+0.9843$ & (14) & $\beta_{z} \rightarrow$ form factor \\
\hline
\end{tabular}


International Journal of Engineering Research and Technology. ISSN 0974-3154, Volume 13, Number 11 (2020), pp. $3790-3794$

(C) International Research Publication House. https://dx.doi.org/10.37624/IJERT/13.11.2020.3790-3794

\section{II.II. CO2 and cost optimization}

The objective functions of cost and $\mathrm{CO} 2$ emissions for this problem are listed in Table 2.

Table 2. Formulation $\mathrm{CO}_{2}$ and cost optimization

\begin{tabular}{|c|c|c|}
\hline $\mathrm{f}_{\text {cost }}=\mathrm{C}_{\mathrm{e}} \mathrm{V}_{\mathrm{e}}+\mathrm{C}_{\mathrm{f}} \mathrm{A}_{\mathrm{f}}+\xi \mathrm{C}_{\mathrm{r}} \mathrm{M}_{\mathrm{r}}+\frac{\mathrm{f}_{\mathrm{c}}}{\mathrm{f}_{\mathrm{c} \text { min }}} C_{\mathrm{c}} \mathrm{V}_{\mathrm{c}}+\mathrm{C}_{\mathrm{b}} \mathrm{V}_{\mathrm{b}}$ & (15) & $\begin{array}{l}\mathrm{C}_{\mathrm{e}} \rightarrow \text { unit cost of excavation } \\
\mathrm{C}_{\mathrm{f}} \rightarrow \text { unit cost of the formwork } \\
\mathrm{C}_{\mathrm{r}} \rightarrow \text { unit cost of reinforcing steel } \\
\mathrm{C}_{\mathrm{c}} \rightarrow \text { unit cost of concrete } \\
\mathrm{C}_{b} \rightarrow \text { unit cost of earth }\end{array}$ \\
\hline $\mathrm{f}_{\mathrm{CO}_{2}}=\mathrm{E}_{\mathrm{e}} \mathrm{V}_{\mathrm{e}}+\mathrm{E}_{\mathrm{f}} \mathrm{A}_{\mathrm{f}}+\xi \mathrm{E}_{\mathrm{r}} \mathrm{M}_{\mathrm{r}}+\frac{\mathrm{f}_{\mathrm{c}}}{\mathrm{f}_{\mathrm{c} \text { min }}} \mathrm{E}_{\mathrm{c}} \mathrm{V}_{\mathrm{c}}+\mathrm{E}_{\mathrm{b}} \mathrm{V}_{\mathrm{b}}$ & (16) & $\begin{array}{l}\mathrm{E}_{\mathrm{e}} \rightarrow \text { unit emission of excavation } \\
\mathrm{E}_{\mathrm{f}} \rightarrow \text { unit emission of the formwork } \\
\mathrm{E}_{\mathrm{r}} \rightarrow \text { unit emission of the reinforcement } \\
\xi \rightarrow \text { factor scale that gives the reinforcement steel term a } \\
\text { magnitude comparable to that of other terms } \\
\mathrm{f}_{\mathrm{c} \text { min }} \rightarrow \text { minimum allowable strength of concrete }\end{array}$ \\
\hline $\mathrm{V}_{\mathrm{e}}=\left(\mathrm{B}+\mathrm{B}_{\mathrm{o}}\right)\left(\mathrm{L}+\mathrm{L}_{\mathrm{o}}\right) \mathrm{D}$ & (17) & $\begin{array}{l}\gamma \rightarrow \text { foundation soil specific weight } \\
\mathrm{c} \rightarrow \text { foundation soil cohesion } \\
\mathrm{N}_{\mathrm{c}}, \mathrm{N}_{\mathrm{q}} \text {, and } \mathrm{N}_{\gamma} \rightarrow \text { dimensionless bearing capacity factors (being } \\
\text { only functions of the foundation soil friction angle - ) } \\
\mathrm{F}_{\mathrm{cs}}, \mathrm{F}_{\mathrm{qs}} \text {, and } \mathrm{F}_{\gamma \mathrm{s}} \rightarrow \text { shape factors } \\
\mathrm{F}_{\mathrm{cd}}, \mathrm{F}_{\mathrm{qd}} \text {, and } \mathrm{F}_{\gamma \mathrm{d}} \rightarrow \text { depth factors }\end{array}$ \\
\hline $\mathrm{A}_{\mathrm{f}}=2 \mathrm{H}(\mathrm{B}+\mathrm{L})$ & (18) & \\
\hline $\mathrm{M}_{\mathrm{r}}=m \mathrm{~V}_{\mathrm{c}}$ & (19) & $m \rightarrow 29.67 \mathrm{~kg} / \mathrm{m}^{3}$ \\
\hline$V_{c}=B L H-V_{r}$ & \multicolumn{2}{|l|}{ (20) } \\
\hline $\begin{array}{c}\mathrm{V}_{\mathrm{b}}=\left[\left(\mathrm{B}+\mathrm{B}_{\mathrm{o}}\right)\left(\mathrm{L}+\mathrm{L}_{\mathrm{o}}\right)-\mathrm{BL}\right] \mathrm{D} \text { for } \mathrm{H} \geq \mathrm{B} \\
\mathrm{V}_{\mathrm{b}}=\mathrm{V}_{\mathrm{e}}-\left[\mathrm{BLH}+\mathrm{b}_{\mathrm{col}} 1_{\mathrm{col}}(\mathrm{D}-\mathrm{H})\right] \text { for } \mathrm{H}<\mathrm{B}\end{array}$ & \multicolumn{2}{|l|}{$(21)$} \\
\hline $\mathrm{f}_{\text {multi }}=\zeta \mathrm{f}_{\text {cost }}+(1-\zeta) \mathrm{f}_{\mathrm{CO}_{2}}$ & \multicolumn{2}{|l|}{$(22)$} \\
\hline
\end{tabular}

\section{II.III. Modified simulated annealing algorithm (MSAA)}

The MSAA is a single-solution metaheuristic based on the cooling of metals phenomenon and it has three main stages that differentiate it from the simulated annealing (SA). Table 3 summarizes these characteristics. For more details, see [5].

Table 3. Modified simulated annealing algorithm

\begin{tabular}{|l|l|l|l|}
\hline $\begin{array}{l}\text { The starting point is } \\
\text { selected by a preliminary } \\
\text { exploration }\end{array}$ & $\mathrm{X}_{\mathrm{PxN}}=\mathrm{I}_{\mathrm{PxN}} \mathrm{X}_{\mathrm{L}}+\operatorname{rand}_{\mathrm{PxN}}\left(\mathrm{X}_{\mathrm{U}}-\mathrm{X}_{\mathrm{L}}\right)$ & $(23)$ & $\begin{array}{l}\mathrm{P} \rightarrow \text { number of points (states) that are desired in the } \\
\text { search space } \\
\mathrm{N} \rightarrow \text { number of dimensions of the problem } \\
\mathrm{I}_{\mathrm{PxN}} \rightarrow \text { identity matrix of size PxN } \\
\mathrm{X}_{\mathrm{L}} \rightarrow \text { lower limit of the problem } \\
\mathrm{X}_{\mathrm{U}} \rightarrow \text { upper limit of the problem } \\
\text { rand } \\
\text { randomness) between 0 and 1 of size PxN. }\end{array}$ \\
\hline $\begin{array}{l}\text { The transition from the } \\
\text { starting point to the new } \\
\text { point is performed by the } \\
\text { addition of random numbers } \\
\text { that are within the defined } \\
\text { radius. }\end{array}$ & $\mathrm{R}_{\mathrm{i}+1}=\mathrm{R}_{\mathrm{i}} \cdot \alpha$ \\
\hline $\begin{array}{l}\text { The probability of accepting } \\
\text { a worse solution is reduced. }\end{array}$ & $\mathrm{P}=\frac{1}{1+\mathrm{e}^{(\Delta \mathrm{f} / \mathrm{T})}}$ & $(24)$ & $\begin{array}{l}\mathrm{R}_{\mathrm{i}} \rightarrow \text { initial radius } \\
\alpha \rightarrow \text { radius reduction coefficient }\end{array}$ \\
\hline
\end{tabular}

The design parameters used for this problem and the value limits for the design variables are listed in Table 4 [2]. The exercise is restricted by a safety factor of 3.0 and maximum settlements of $25 \mathrm{~mm}$. 
Table 4. Input parameters and Design variables

\begin{tabular}{|c|c|c|}
\hline Input parameter & Symbol & Value \\
\hline Internal friction angle of soil $\left({ }^{\circ}\right)$ & $\phi$ & 35 \\
\hline Unit weight of soil $\left(\mathrm{kN} / \mathrm{m}^{3}\right)$ & $\gamma_{\mathrm{s}}$ & 18.5 \\
\hline Poisson ratio of soil & $v$ & 0.3 \\
\hline Modulus of elasticity of soil (MPa) & $\mathrm{E}$ & 50 \\
\hline Applied vertical force $(\mathrm{kN})$ & $\mathrm{P}$ & 3000 \\
\hline Over excavation length (m) & $\mathrm{L}_{\mathrm{o}}$ & 0.3 \\
\hline Over excavation width $(\mathrm{m})$ & $\mathrm{B}_{\mathrm{o}}$ & 0.3 \\
\hline Thickness of footing $(\mathrm{m})$ & $\mathrm{H}$ & 0.6 \\
\hline Factor of safety for bearing capacity & FS & 3 \\
\hline Maximum allowable settlement (mm) & $\delta$ & 25 \\
\hline Design variables & Lower bound & Upper bound \\
\hline $\mathrm{B}(\mathrm{m})$ & 0.01 & 5.0 \\
\hline $\mathrm{L}(\mathrm{m})$ & 0.01 & 5.0 \\
\hline $\mathrm{D}(\mathrm{m})$ & 0.50 & 2.0 \\
\hline
\end{tabular}

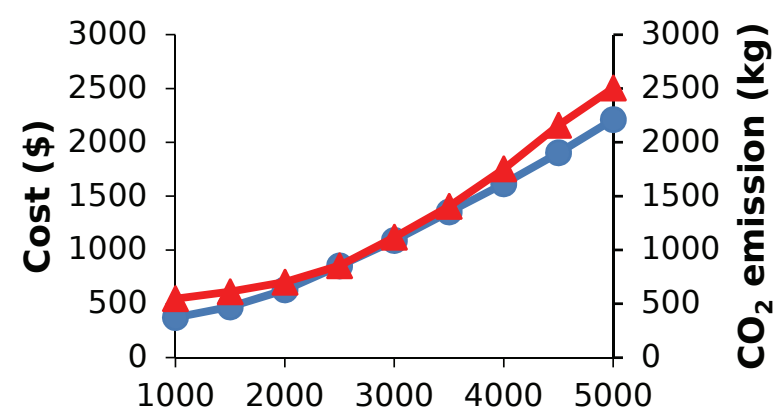

Applied load (kN)

(a)

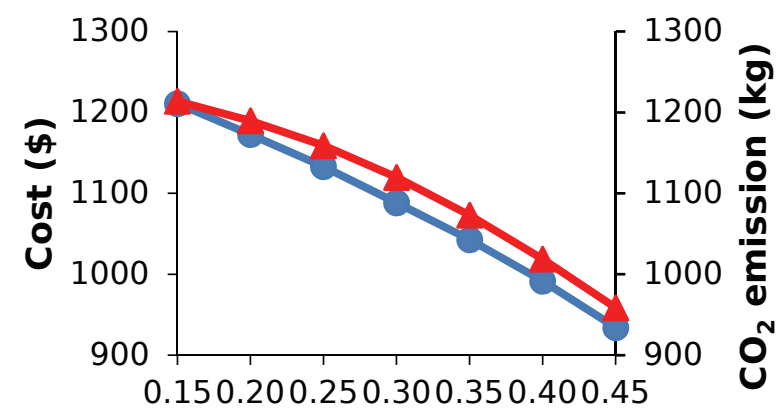

Poisson ratio

(c)

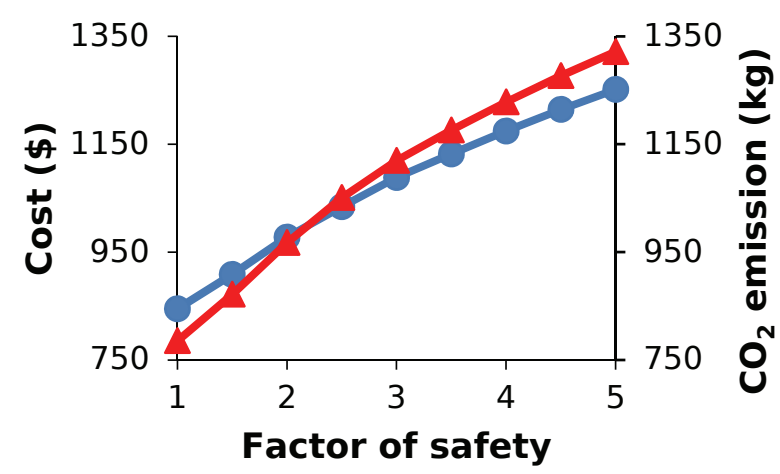

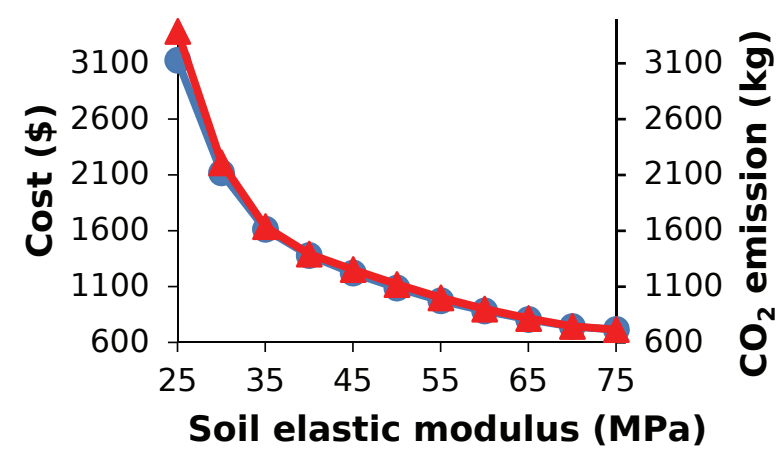

(b)

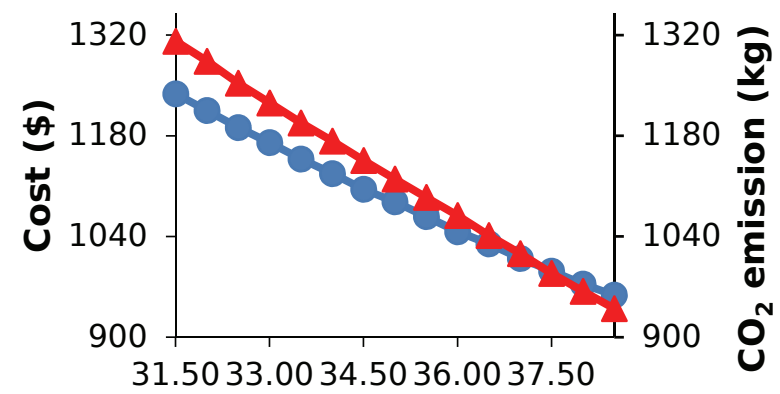

Angle of internal friction $\left({ }^{\circ}\right)$

(d)

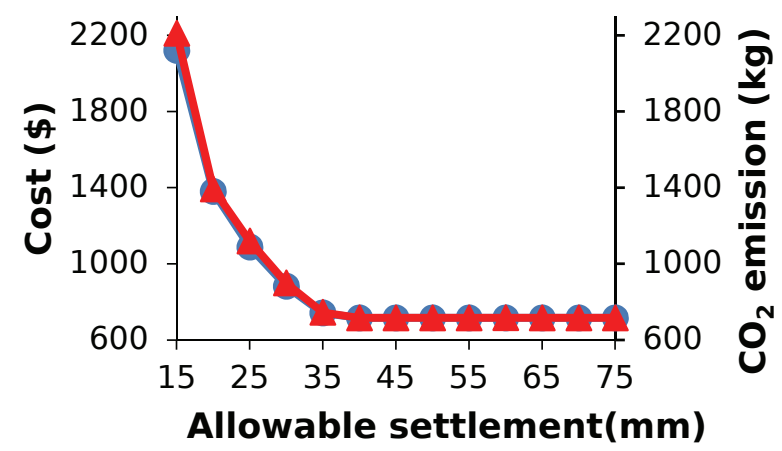

(f)

\section{Average cost Average $\mathrm{CO}_{2}$ emissions}

Figure 2. Effects of: (a) applied load, (b) soil elastic modulus, (c) Poisson ratio, (d) angle of internal friction, (e) factor of safety and (f) allowable settlement on average cost and average $\mathrm{CO}_{2}$ emission designs 


\section{RESULTS AND DISCUSSIONS}

100 runs were executed, and the average cost and $\mathrm{CO} 2$ emission designs are calculated for a typical range of applied load, soil elastic modulus, Poisson ratio, angle of internal friction, factor of safety and allowable settlement. While the number of runs is arbitrary, it should be adequate to provide reliable statistics on the general quality of the solutions and the convergence of the MSAA. It is also important to note that all presented MSAA designs are feasible. The algorithm was coded in Matlab.

Figure 2 shows de effects of design parameters on cost and $\mathrm{CO} 2$ emission in reinforced concrete footings. Figure 2(a) shows that the cost and $\mathrm{CO} 2$ emissions increase as the applied column load increases. Figure 2(b) shows that as the soil becomes more rigid, the cost and $\mathrm{CO} 2$ emission values decrease considerably. Figure 2(c) shows that as the soil Poisson's ratio increases, the cost and $\mathrm{CO} 2$ emission values decrease slightly. Figure 2(d) shows that as the internal friction angle of the soil increases, the cost and $\mathrm{CO} 2$ emission values decrease. Figure 2(e) shows that as the required minimum safety factor increases, the cost and $\mathrm{CO} 2$ emission values increase. Figure 2(f) shows that as the maximum allowed settlement increases, the cost and $\mathrm{CO} 2$ emissions of the footing designs are significantly reduced to a point where the settlement no longer controls the project $(\delta>35$ $\mathrm{mm})$.

\section{CONCLUSIONS}

In this paper the impact of different design parameters on the optimization of cost and $\mathrm{CO} 2$ emission in reinforced concrete footings using a metaheuristic algorithm was assessed. The metaheuristic algorithm implemented was Modified Simulated Annealing Algorithm. From the results obtained, it is concluded that both cost and $\mathrm{CO} 2$ emissions are highly sensitive to changes in the applied load, in the modulus of soil elasticity and in the maximum allowed settlement. The soil Poisson's ratio, the internal friction angle and the safety factor have less impact on the cost and $\mathrm{CO} 2$ emission values.

\section{REFERENCES}

[1] Das BM. Principios de Ingeniería de Cimentaciones. Quinta edición. 2006.

[2] Camp C V., Assadollahi A. CO2 and cost optimization of reinforced concrete footings using a hybrid big bang-big crunch algorithm. Struct Multidiscip Optim 2013;48:41126. doi:10.1007/s00158-013-0897-6.

[3] Wang Y, Kulhawy FH. Economic Design Optimization of Foundations. J Geotech Geoenvironmental Eng 2008;134:1097-105. doi:10.1061/(ASCE)10900241(2008)134:8(1097).

[4] Khajehzadeh M, Taha MR, El-Shafie A, Eslami M. Modified particle swarm optimization for optimum design of spread footing and retaining wall. J Zhejiang Univ A
2011;12:415-27. doi:10.1631/jzus.A1000252.

[5] Millán Páramo C, Begambre Carrillo O, Millán Romero E. Propuesta y validación de un algoritmo Simulated annealing modificado para la solución de problemas de optimización. Rev Int Métodos Numéricos Para Cálculo y Diseño En Ing 2014;30:264-70. doi:10.1016/j.rimni.2013.10.003.

[6] Millán Páramo C, Begambre Carrillo O. Solución de problemas de optimización topológica empleando el Algoritmo Simulated Annealing Modificado. Rev Int Métodos Numéricos Para Cálculo y Diseño En Ing 2016;32:65-9. doi:10.1016/j.rimni.2014.11.005.

[7] Millan-Paramo C. Modified Simulated Annealing Algorithm for Discrete Sizing Optimization of Truss Structure. Jordan J Civ Eng 2018;12:683-97.

[8] Millán-Páramo C, Matoski A, Mazer W. Algoritmo simulated annealing modificado para diseño óptimo de armaduras con variables continuas. Rev Tecnol En Marcha 2017;30:142-57. doi:10.18845/tm.v30i2.3209.

[9] Millan-Paramo C, Abdalla Filho JE. Size and Shape Optimization of Truss Structures with Natural Frequency Constraints Using Modified Simulated Annealing Algorithm. Arab J Sci Eng 2020;45:3511-25. doi:10.1007/s13369-019-04138-5.

[10] Millán Páramo C, Millán Romero E. Algoritmo simulated annealing modificado para minimizar peso en cerchas planas con variables discretas. INGE CUC 2016;12:9-16. doi:10.17981/ingecuc.12.2.2016.01.

[11] Millan-Paramo C, Filho J. Modified simulated annealing algorithm for optimal design of steel structures. Rev Int Métodos Numér Cálc Diseño Ing 2019;35:1-12. doi:10.23967/j.rimni.2019.03.003.

[12] Millan-Paramo C, Filho JEA. Exporting water wave optimization concepts to modified simulated annealing algorithm for size optimization of truss structures with natural frequency constraints. Eng Comput 2019. doi:10.1007/s00366-019-00854-6.

[13] Arrieta Baldovino J de J, Millan-Paramo C, Izzo RL dos $\mathrm{S}$, Moreira E. Optimización de CO2 y costo de zapatas de concreto reforzado sobre un suelo tratado con cal usando algoritmo de recocido simulado modificado. INGE CUC 2020;16:1-16. 